\title{
Historical occurrence of the short-neck clam, Ruditapes philippinarum (Adams \& Reeve, 1850), on the sandy flats of Ariake Bay, Kyushu, western Japan
}

\author{
Shoichi Shimoyama ${ }^{1, *}$, Toshiniko Ichinara ${ }^{2}$, KaORi Tsukano ${ }^{3}$, Minami Kabashima ${ }^{3}$, \\ NORIYUKI MOMOSHIMA ${ }^{4}$, TOMOHIRO KOMORITA ${ }^{5} \&$ HIROAKI TSUTSUMI $^{5}$ \\ ${ }^{1}$ Institute of Lowland and Marine Research, Saga University, Honjyo 1, Saga 840-8502, Japan \\ ${ }^{2}$ Fukken Co., Ltd. Kyushu Branch Office, 3-12-24 Hakataeki Higashi, Hakata-Ku, Fukuoka 812-0013, Japan \\ ${ }^{3}$ Faculty of Sciences, Kyushu University, Hakozaki, Fukuoka 812-8581, Japan \\ ${ }^{4}$ Central Institute of Radioisotope Sciences and Safety, Kyushu University, 744 Motooka, Fukuoka 819-0395, Japan \\ ${ }^{5}$ Faculty of Environmental \& Symbiotic Sciences, Prefectural University of Kumamoto, 3-1-100, Tsukide, Kumamoto 862-8502, \\ Japan
}

Received 2 September 2014; Accepted 30 November 2015 Responsible Editor: Akira Asakura

\begin{abstract}
Long plate-like sediment samples were collected using a Geoslicer technique at five different sites on the sandy tidal flats along the eastern coast of Ariake Bay, Kyushu, western Japan, where there are major harvesting sites of the edible clam Ruditapes philippinarum. The deposition process of the sediment and fossil contents of the shellfish in these Geosliced samples were examined, dating the deposition process of the sediment to at least 400 years ago with a trace of a giant tsunami that occurred in 1792, and radio-active matters $\left({ }^{14} \mathrm{C}\right.$ contained in the wood pieces, ${ }^{210} \mathrm{~Pb}$ and

${ }^{137} \mathrm{Cs}$ ), and describing the distribution of the fossil contents of the shellfish in the sediment samples. These results indicate that dense patches of $R$. philippinarum were established later than 180 to 190 years ago at the sampling sites, and it is very likely that this species was introduced to the sandy tidal flats in Ariake Bay in an anthropogenic way. This conclusion coincides with archaeological evidence collected from shell mounds established in the coastal areas of Ariake Bay during the Jomon and Tumulus Periods (13,000 BC to $600 \mathrm{AD})$. Ruditapes philippinarum was very rare among fossil shells collected from the shell mounds except one created at the mouth of the bay. This species does not favor the water conditions in the estuary where the salinity tends to be variable due to the inflow of freshwater from rivers. It seems that various kinds of human manipulation are essential for $R$. philippinarum to be maintained in large numbers on the tidal flats at the mouths of the rivers in the inner parts of Ariake Bay.
\end{abstract}

Key words: Ariake Bay, Geoslicer cores, Ruditapes philippinarum, shell mounds, tidal flats

\section{Introduction}

The Japanese carpet shell, Ruditapes philippinarum (Adams \& Reeve, 1850), a species of edible clam, is one of the most common species in the macro-benthic communities occurring on sandy tidal flats throughout the coastal areas of Japan, Korea and China (Magni et al. 2000, Ishii et al. 2001, Kakino 2006, Kudo et al. 2006, Komorita et al. 2009, Mizuno et al. 2009). It is a northern West Pacific species, the known distribution of which includes the Philippines, the South and East China Seas, the Yellow

*Corresponding author: Shoichi Shimoyama; E-mail, cshmym@diary. ocn.ne.jp
Sea, the Sea of Japan, the Sea of Okhotsk, and the southern Kuril Islands. In those areas, mariculture was initiated from traditional fishing activities by seeding with animals collected in the wild. Of considerable commercial value, $R$. philippinarum has been introduced also to other parts of the world including the Pacific coast of North America and European waters, where they have become permanently established (FAO 2015).

This species often establishes colonies with a density of over $1 \mathrm{~kg} \mathrm{~m}^{-2}$ in Ariake Bay (Tsutsumi 2006, Tsutsumi et al. 2003). The total harvest of this species in Japan fluctuated between approximately 120,000 and 160,000 tons in the 1970s and the early 1980s but decreased drastically from the latter half of the 1980s (Ishii et al. 2001, Seki- 
guchi \& Ishii 2003, Matsukawa et al. 2008, Mizuno et al. 2009). Various causes for this decline have been suggested, including: loss of the tidal flats; occurrence of hypoxic water (Kakino 2006, Yamaguchi \& Uchikawa 2005); drastic decrease in salinity due to heavy rain (Kakino 2006); deposition of mud and/or high concentration of manganese (Fujimori et al. 1983, Tsutsumi 2005, Tsukuda \& Tsutsumi 2008); infection by protozoan parasites (Hamaguchi et al. 2002, Choi \& Park 2010); increase in mortality of planktonic stage (Sekiguchi \& Ishii 2003); predation by rays and gastropods (Nakahara \& Nasu 2002, Ohkoshi 2004); competition with ghost shrimp (Tamaki 2004). However, the actual mechanism(s) causing the drastic decrease in the harvest are still not clear. In 2010, only about 27,000 t were harvested from Japanese coasts (Ministry of Agriculture, Forestry and Fisheries 2014).

Some of the most popular harvesting sites for $R$. philippinarum in Japan are the sandy tidal flats of Ariake Bay, in western Kyushu (Fig. 1). There, vast areas of sandy tidal flats of over 7,000 ha in total area still remain along the eastern coast of the bay, although approximately $40 \%$ of the tidal flats in the area have disappeared during the last half-century (Takahashi 1994). In the 1970s, the annual harvest of $R$. philippinarum on the sandy tidal flats of Ariake Bay reached over $100,000 \mathrm{t}$ per year, which accounted for more than $70 \%$ of the national total harvested in those days. However, the clam harvesting fishery in Ariake Bay collapsed in the 1980s, and the annual harvest has declined to less than $10,000 \mathrm{t}$ per year since the 1990s (Sasaki 1999, Kikuchi 2000, Tsutsumi 2005, Ministry of
Environment 2006, Shinohara et al. 2009), even though the total area of sandy tidal flat habitat favored by R. philippinarum has decreased only slightly in Ariake Bay since the 1960s (Environment Agency 1994). Therefore, the drastic decrease of the national total harvest of this species is mainly due to the collapse of the clam harvest in Ariake Bay since the 1980s (Tsutsumi 2006).

The present study focuses on changes in the sedimentation of sand and silt and the occurrence of shellfish including $R$. phlippinarum on the sandy tidal flats in Ariake Bay over the past 400 years from the standpoint of geological history. Long plate-like sediment samples over $5 \mathrm{~m}$ in length were collected using a Geoslicer technique at five different sites on the sandy tidal flats along the eastern coast of Ariake Bay, at major harvesting sites of R. philippinarum. The deposition process of sediment and the fossil contents of the shellfish in these geosliced samples were examined, calibrated by deposits from a tsunami caused by the eruption of a volcano, Mt. Unzen, located on the Shimabara Peninsula facing Ariake Bay in 1792. Radioactive content $\left({ }^{14} \mathrm{C}\right.$ contained in pieces of wood; and ${ }^{137} \mathrm{Cs}$, and ${ }^{210} \mathrm{~Pb}$ in the sediment samples) was also measured, and used to describe the distribution of the fossil component of shellfish in the sediment samples. Excavation records of shell mounds found in the coastal areas of Ariake Bay (which were established during the Jomon and Tumulus Periods; $13,000 \mathrm{BC}$ to $600 \mathrm{AD}$ ) were examined to compare the species composition of edible shellfish in ancient times with that of the present. From these results, historical changes in the occurrence of $R$. philippinarum on the san-

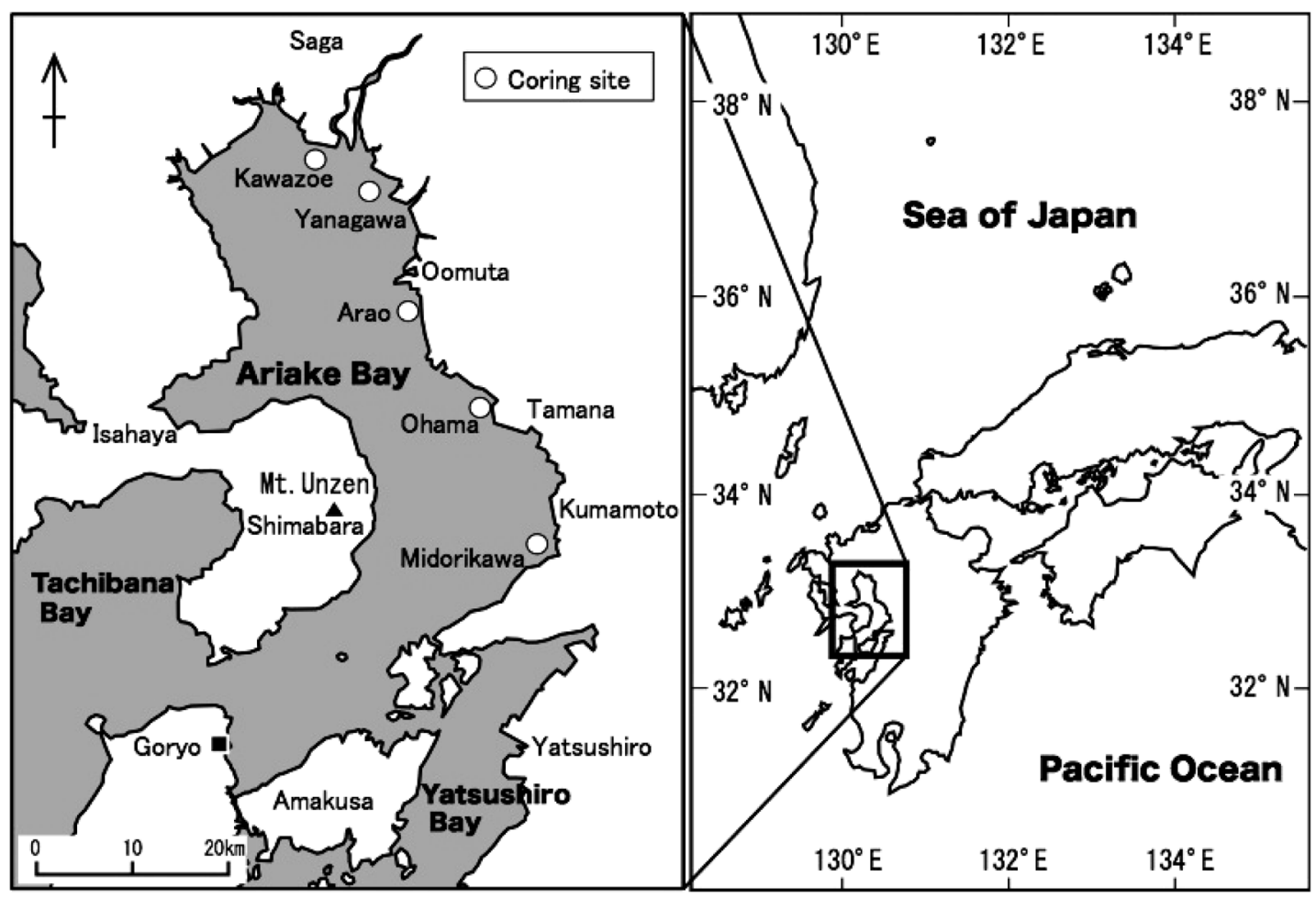

Fig. 1. Map of the sampling areas. 
dy tidal flats in Ariake Bay were obtained as a contribution towards understanding the drastic decrease in the harvest independent of the decrease of potential habitats since the 1980s.

Table 1. GPS information for the five different coring sites in Ariake Bay.

\begin{tabular}{ccc}
\hline Tidai flat sampling site & Map coordinates & Date \\
\hline \hline Off Kawazoe, Saga Pref. & $33^{\circ} 07^{\prime} 43.75^{\prime \prime} \mathrm{N}$ & Sept. 29, 2005 \\
& $130^{\circ} 17^{\prime} 55.67^{\prime \prime} \mathrm{E}$ & \\
\hline Off Yanagawa, Fukuoka Pref. & $33^{\circ} 06^{\prime} 34.65^{\prime \prime} \mathrm{N}$ & July 14. 2008 \\
& $130^{\circ} 22^{\prime} 11.97^{\prime \prime} \mathrm{E}$ & \\
\hline Arao, Kumamoto Pref. & $32^{\circ} 58^{\prime} 56.99^{\prime \prime} \mathrm{N}$ & April. 24, 2004 \\
& $130^{\circ} 25^{\prime} 37.32^{\prime \prime} \mathrm{E}$ & \\
\hline Kikuchi River Tamana, & $33^{\circ} 51^{\prime} 35.79^{\prime \prime} \mathrm{N}$ & May 16. 2007 \\
Kumamoto Pref. & $130^{\circ} 30^{\prime} 50.14^{\prime \prime} \mathrm{E}$ & \\
\hline Midorikawa (River Midori), & $33^{\circ} 43^{\prime} 12.13^{\prime \prime} \mathrm{N}$ & Aug. 26, 2011 \\
Kumamoto City, Kumamoto Pref. & $130^{\circ} 33^{\prime} 48.92^{\prime \prime} \mathrm{E}$ & \\
\hline
\end{tabular}

\section{Materials and Methods}

\section{Study areas}

Ariake Bay is located on the western side of Kyushu $\left(33^{\circ} 00^{\prime} \mathrm{N}, 130^{\circ} 20^{\prime} \mathrm{E}\right.$; Fig. 1). It is the largest enclosed bay in Kyushu with an area of about $1,700 \mathrm{~km}^{2}$. The maximum tidal range reaches over six meters in the innermost areas of the bay during spring tides, and includes large areas of tidal flats totaling over $20,000 \mathrm{ha}$. On the eastern coast of the bay, the sediment of the tidal flats is mostly sand and silt. Five sampling points were allocated (at Kawasoe, Yanagawa, Arao, Ohama, and Midorikawa; Table 1) to collect the geoslice sediment samples on the sandy tidal flats, which are popular harvesting sites for R. philippinarum.

\section{Sediment sampling}

Samples were taken used the geoslicer technique, which has been commonly applied to soil sampling at alluvial lowlands composed of unconsolidated water-saturated soft
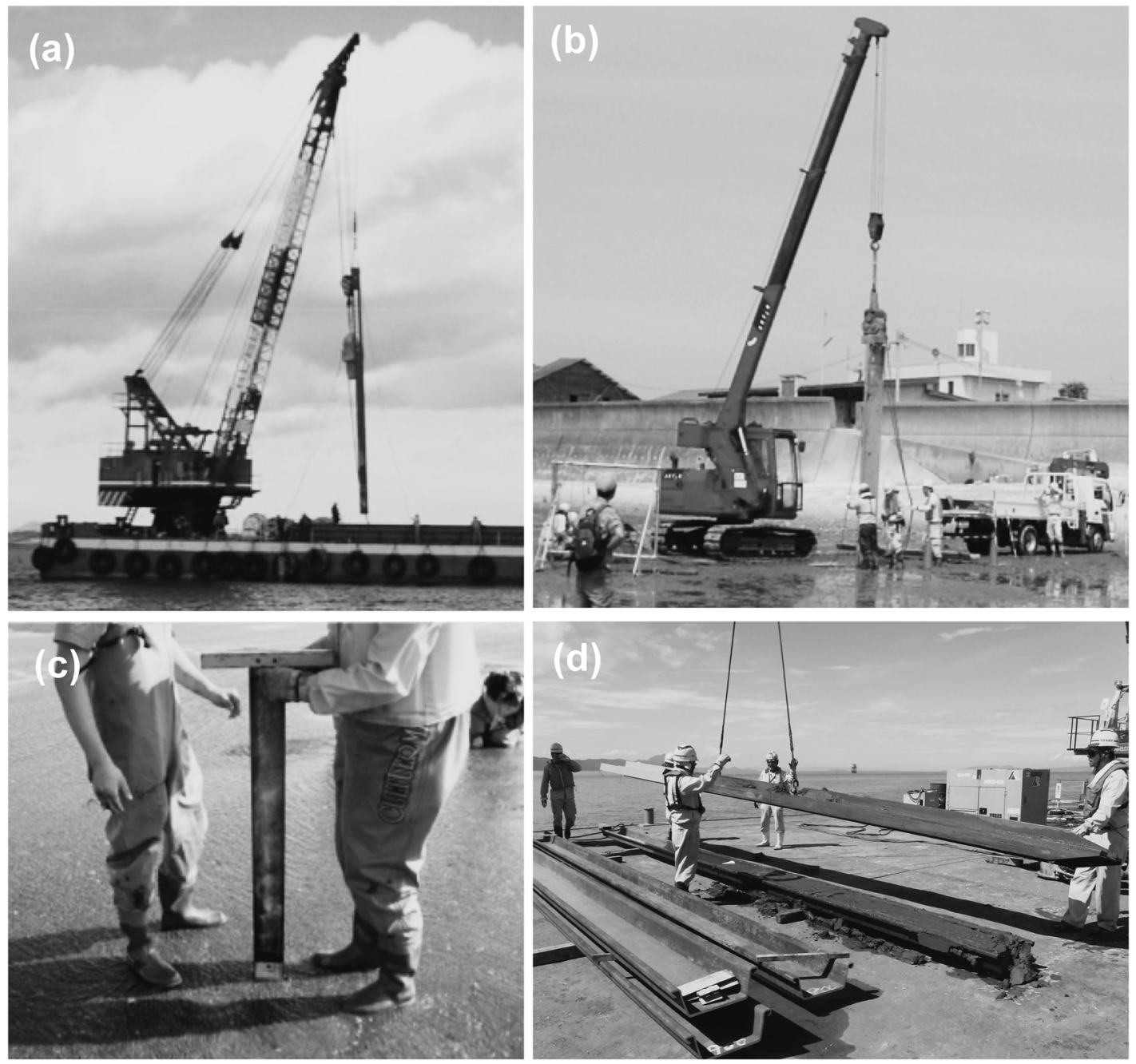

Fig. 2. Sediment sampling with the geoslicer technique: (a) from a workbench ship with a crane in shallow coastal waters; (b) using a crane standing on the tidal flats; (c) using a portable geoslicer; and (d) A sediment core sample collected with the geoslicer technique. 
sediments (Nakata \& Shimazaki 1997, Haraguchi et al. 1998). This technique enables large, plate-like sediment samples to be obtained with the inherent structure of the sediment profile retained intact. The sampling gear consists of three parts: a sampling tray with narrow flanges, a shutter plate, and two clips that fasten the shutter plate to the sampling tray. At Kawazoe, Yanagawa, and Midorikawa, the sampling tray, about $5 \mathrm{~m}$ in length, was suspended from a crane on a workbench ship, and inserted in the sediment with a vibrating hammer (Fig. 2a). At Arao, it was inserted from a mobile crane standing directly on the tidal flats (Fig. 2b). At Ohama, a portable sampling tray, about $1 \mathrm{~m}$ in length, was inserted into the sediment by hand (Fig. 2c). For each sample, a shutter plate was inserted along the sampling tray in the sediment with the same methods as the sampling trays, and was fastened to the sampling tray with two clips. Finally, the apparatus was lifted out to remove the sediment sample (Fig. 2d).

Sediment sampling was conducted at Arao on April 24 in 2004; at Kawazoe on September 29, 2005; Ohama on May 16, 2007; Yanagawa on July 14, 2008; and Midorikawa on August 26, 2011. At each site, 3 to 5 of the geoslice samples were collected for observation of the sedimentary structure; 3 to 5 samples for dating of sediment; and 4 to 11 samples for fossil shell analysis. The sedimentary structure of the geoslice samples was observed on land adjacent to the sampling site within a few days of obtaining the sample, and schemata of the distribution of sediment types within the profiles were drawn. A sub-sample of approximately $30 \mathrm{~g}$ of sediment from one geoslice was used for gamma spectrometry and $22-65 \mathrm{~g}$ of sediment was subsampled from a separate geoslice at $5 \mathrm{~cm}$ depth intervals to determine the faunal composition of fossil shells. Pieces of wood in the geoslice samples collected at Midorikawa were used for ${ }^{14} \mathrm{C}$ dating.

\section{Dating the sediment with ${ }^{14} \mathrm{C}$}

A Libby half-life of 5,568 years was used to determine the ${ }^{14} \mathrm{C}$ age of wood samples, following Stuiver \& Polach (1977). Carbon was recovered as $\mathrm{CO}_{2}$ by combustion of the wood pieces and acid decomposition of the shell pieces, and then converted to graphite for accelerator mass spectrometry (AMS) analysis. The isotope ratio of ${ }^{14} \mathrm{C} /{ }^{12} \mathrm{C}$ was obtained using a IAA-AMS 3MV AM spectrometer at the Shirakawa Analysis Center of the Institute of Accelerator Analysis Ltd., Kawasaki, Japan (IAA). The ${ }^{14} \mathrm{C}$ year was calculated from the ${ }^{14} \mathrm{C} /{ }^{12} \mathrm{C}$ ratio and $\mathrm{d}^{13} \mathrm{C}$ value to calendar years Before Present (yBP) using IntCal09 (Reimer et al. 2009), where 1950 AD is defined as "Modern" by convention. The ${ }^{14} \mathrm{C}$ age was determined by the IAA.

\section{Dating the sediment with ${ }^{137} \mathrm{Cs}$ and ${ }^{210} \mathrm{~Pb}$}

Sub-sampled sediment for gamma spectrometry was dried at $105^{\circ} \mathrm{C}$ in an air oven. After removing pieces of shell by hand, samples were grounded with a pestle and mortar, and each sub-sample was placed into a plastic U-8 container (48 $\mathrm{mm}$ in inner diameter) to a maximum height of $25 \mathrm{~mm}$. The radioactivity of the sample was measured using a gamma spectrometer equipped with a low-background type Ge detector (GMX, relative efficiency 55.4\%, EG\&G ORTEC Ltd., USA) shielded with massive lead blocks (15 cm in thickness) and $4 \mathrm{~mm}$ thick oxygen-free copper inside. The spectrum was stored in a 4096 multichannel analyzer for more than $48 \mathrm{~h}$, and analyzed with a computer program, "Gamma Studio" (SEIKO EG\&G Ltd., Japan). The counting efficiency for each gamma energy peak was estimated from counting efficiency curves which were prepared using a set of gamma standard U-8 sources with different heights certified by the Japan Radioisotope Association. The sedimentation mass was calculated from the wet and dry weights of each increment. The depth profiles of ${ }^{210} \mathrm{~Pb}$ and ${ }^{137} \mathrm{Cs}$ against the cumulative sedimentation mass from the surface of the sediment were constructed to calculate the sedimentation rate, and to estimate the sedimentation year.

\section{Fossil shell analyses}

Sediment samples of $35 \mathrm{~cm}$ in width and $10 \mathrm{~cm}$ in thickness were subsampled for fossil shells from the geoslice samples every $20 \mathrm{~cm}$, except for samples from Ohama (where sample sizes were $9 \mathrm{~cm}$ in width and $2 \mathrm{~cm}$ in thickness because sampling used the portable geoslice technique). Each sediment subsample was sieved on a $2 \mathrm{~mm}$ mesh and fossil shells were picked out by hand. All molluscan fossil shells were identified to species level. Complete and damaged shells of each species were counted as one specimen where the umbonal area was preserved for bivalve species. Dominant species in each sediment sample were determined by differences between the theoretical and the measured values, according to the law of MacArthur series (MacArthur 1960; see Shimoyama \& Hamano 1980 for details). In the other words, the species where the measured individual number was larger than the theoretical numbers was treated as a dominant species. The deepest bivalve assemblages with $R$. philippinarum were determined in all of the geoslice samples for fossil shell analysis in order to estimate the earliest date of colonization by $R$. philippinarum at each of the five sampling sites.

\section{Results}

\section{Historical structure of the sediment samples}

Fig. 3 shows images of the sedimentary slice profiles obtained at the five different sampling sites in Ariake Bay. In four of these five samples, a disturbed layer was identified at depths of $150 \mathrm{~cm}$ at Kawazoe, $90 \mathrm{~cm}$ at Yanagawa, $130 \mathrm{~cm}$ at Arao, and $220 \mathrm{~cm}$ at Midorikawa. Fig. 4a is a magnified image at the disturbed layer of the sample collected at Midorikawa. Current ripples (Ts) are indicative of flow from the offshore side toward the onshore side. Scoria gravels produced by a volcanic eruption or the reworking 


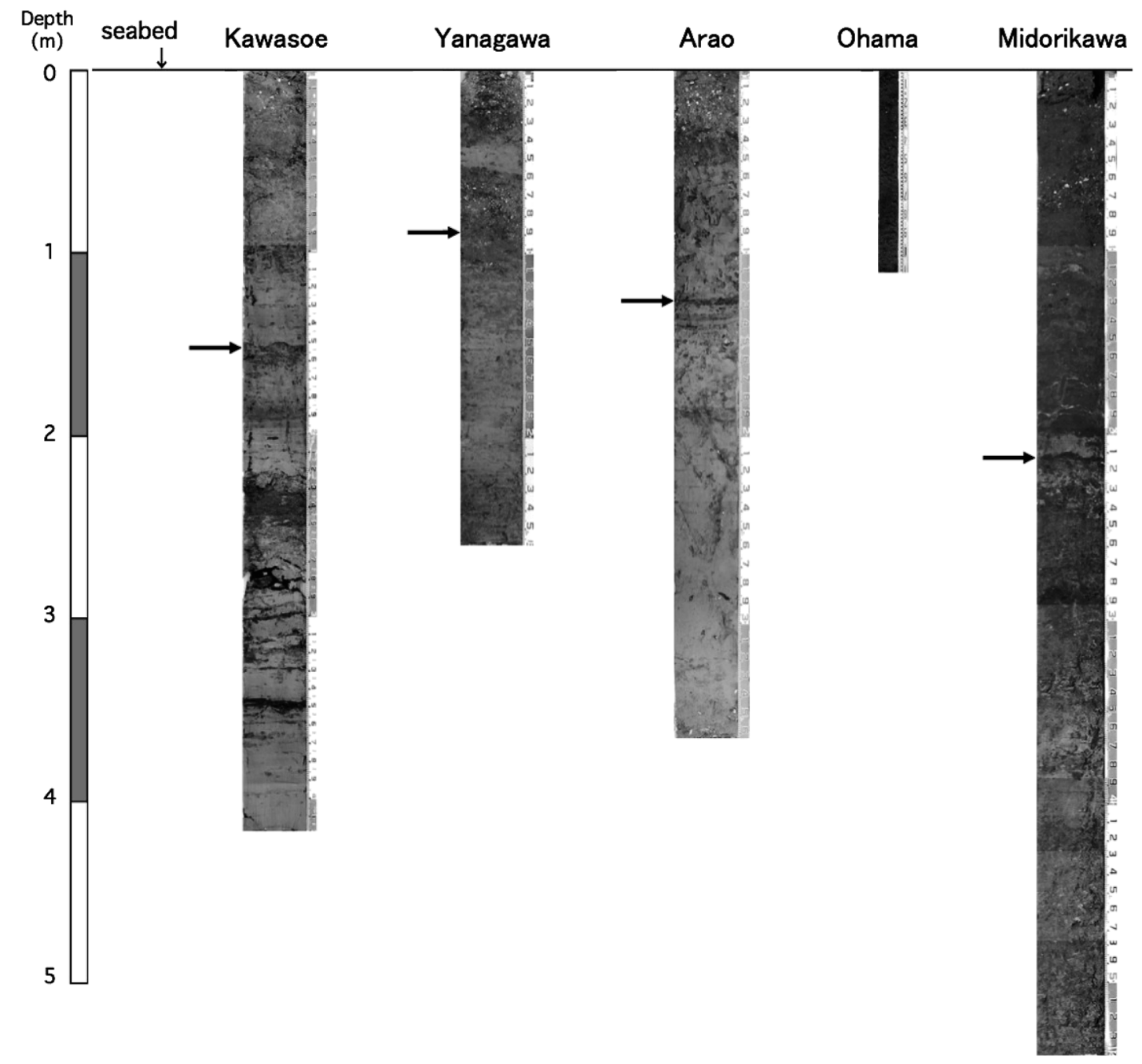

Fig. 3. Images of the sediment profiles collected at the five different sampling sites in Ariake Bay. Arrows indicate the presence of the disturbed layer made by the tsunami resulting from the eruption of Mt. Unzen, in 1792.

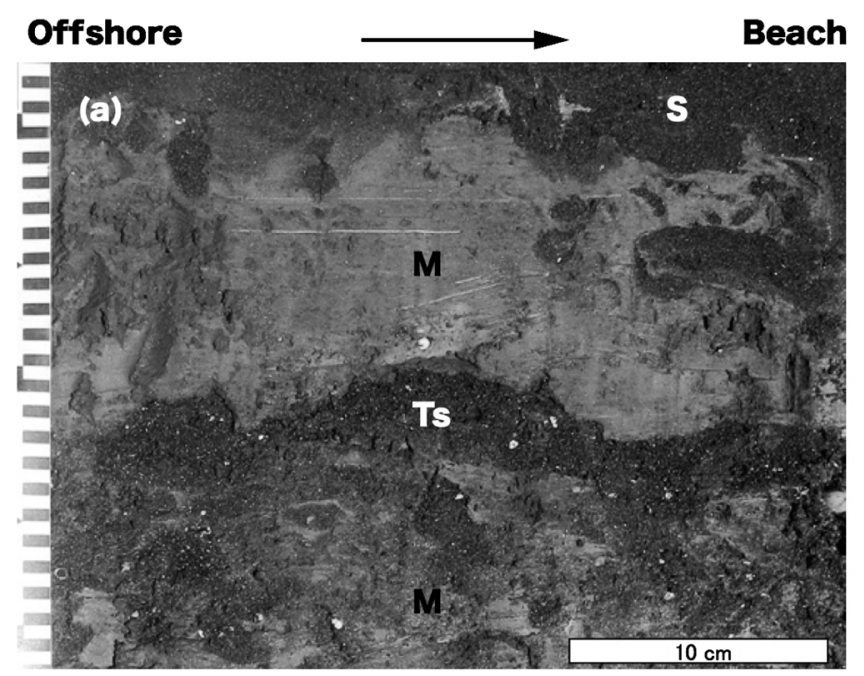

(b)

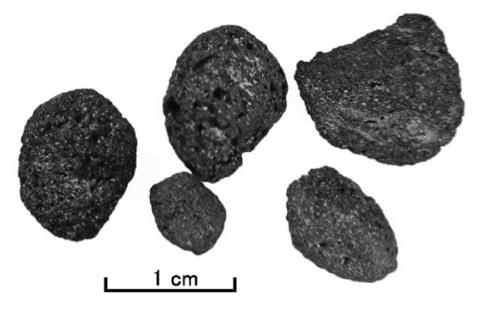

Fig. 4. (a) A magnified image around the disturbed layer created at a depth of about $220 \mathrm{~cm}$ in the sediment profile collected at Midorikawa on August 26, 2011. Abbreviations: Ts deposits made by the 1792 tsunami; M mud; S sand. (b) Scoria gravels collected from the disturbed layer (Ts). 
were found in this Ts layer (Fig. 4(b)).

Table 2 lists the results of ${ }^{14} \mathrm{C}$ dating of wood pieces sampled, which were found in three different layers of the sediment profile collected at Midorikawa. The wood sample from the $210 \mathrm{~cm}$ layer was apparently deposited between 1798 and $1850(2 \sigma, 41 \%)$. This estimated age is immediately after the time when Mt. Unzen (located in Shimabara Peninsula facing Ariake Bay) partly collapsed due to an explosion halfway up the volcano, which in 1792 caused a massive tsunami exceeding $20 \mathrm{~m}$ in height $(\mathrm{Ka}-$ tayama 1974). These events, including the collapse of the mountain and occurrence of the tsunami, are referred in Japan as the Shimabara Catastrophe, which appears to cor- respond to the disturbed layer at $220 \mathrm{~cm}$ in the sediment profile from Midorikawa. All of other disturbed layers characterized by the presence of current ripples and scoria gravels in sediment profiles collected at three other sites (Kawasoe, Yanagawa, and Arao) are also best interpreted as being made by the tsunami, although the depth of the disturbed layer varies, apparently due to different sedimentation rates. The sample collected at Ohama apparently did not reach the disturbed layer made by the tsunami.

Table 3 shows the age indices recognized in the sedimentary slice profiles with the results of dating with radioactive intensities of ${ }^{137} \mathrm{Cs}$ and ${ }^{210} \mathrm{~Pb}$ and the trace of the tsunami of 1792. The peak of the radioactive intensity of ${ }^{137} \mathrm{Cs}$

Table 2. Results of ${ }^{14} \mathrm{C}$ dating of wood pieces found in the sediment samples at Midorikawa in Ariake Bay.

\begin{tabular}{|c|c|c|c|c|c|c|}
\hline Core & Depth (m) & Labo number & ${ }^{14} \mathrm{C}$ age & Cal yBP $(2 \sigma)$ & $\begin{array}{c}\text { Calibrated age* } \\
(2 \sigma: \mathrm{AD} / \mathrm{BC})\end{array}$ & Material dated \\
\hline MDGS3 & 0.5 & IAAA-121287 & Modern & & & Wood fragment \\
\hline \multirow[t]{5}{*}{ MDGS3 } & 0.7 & IAAA-121288 & $160 \pm 20$ & $252-284(0.16)$ & AD 1666-1698 (0.16) & Wood fragment \\
\hline & & & & $166-225(0.41)$ & AD 1725-1784 (0.41) & \\
\hline & & & & $135-184(0.11)$ & AD $1796-1815(0.11)$ & \\
\hline & & & & $72-115(0.09)$ & AD $1835-1878(0.09)$ & \\
\hline & & & & $0-34(0.19)$ & AD 1916-1952 (0.19) & \\
\hline MDGS3 & 1.3 & IAAA-121289 & $340 \pm 20$ & $314-478(0.95)$ & AD 1472-1636 (0.95) & Wood fragment \\
\hline \multirow[t]{3}{*}{ MDGS3 } & 1.5 & IAAA-121290 & $300 \pm 20$ & $445-454(0.16)$ & AD 1496-1505 (0.16) & Wood fragment \\
\hline & & & & $348-438(0.67)$ & AD 1512-1602 (0.67) & \\
\hline & & & & $297-334(0.27)$ & AD $1616-1653(0.27)$ & \\
\hline \multirow[t]{3}{*}{ MDGS3 } & 1.9 & IAAA-121291 & $520 \pm 20$ & $609-622(0.06)$ & AD 1328-1341 (0.06) & Wood fragment \\
\hline & & & & $511-555(0.90)$ & AD $1395-1439(0.90)$ & \\
\hline & & & & $241-274(0.15)$ & AD 1676-1709 (0.15) & \\
\hline \multirow[t]{4}{*}{ MDGS2 } & 2.1 & IAAA-111783 & $140 \pm 20$ & $172-233(0.23)$ & AD $1717-1778(0.23)$ & Wood fragment \\
\hline & & & & $100-152(0.41)$ & AD $1798-1850(0.41)$ & \\
\hline & & & & $9-40(0.17)$ & AD 1910-1941 (0.17) & \\
\hline & & & & $906-964(0.84)$ & AD 986-1046 (0.84) & \\
\hline \multirow[t]{2}{*}{ MDGS2 } & 2.3 & IAAA-111784 & $1,000 \pm 20$ & $827-853(0.09)$ & AD 1093-1121 (0.09) & Wood fragment \\
\hline & & & & $801-810(0.02)$ & AD $1140-1149(0.02)$ & \\
\hline \multirow[t]{3}{*}{ MDGS2 } & 2.9 & IAAA-111785 & $1,250 \pm 20$ & $1128-1270(0.93)$ & AD 680-822 (0.93) & Wood fragment \\
\hline & & & & $1090-1108(0.03)$ & $A D 842-860(0.03)$ & \\
\hline & & & & $2306-2351(0.81)$ & BC $402-357(0.81)$ & \\
\hline \multirow[t]{2}{*}{ MDGS2 } & 4.9 & IAAA-111786 & $2,290 \pm 20$ & $2205-2233(0.12)$ & BC $284-256(0.12)$ & Wood fragment \\
\hline & & & & $2185-2195(0.03)$ & BC $246-235(0.03)$ & \\
\hline
\end{tabular}

* Ages were calibrated used with Intcal09 programs (Reimer et al. 2009)

$2 \sigma$ shows $95.4 \%$ probability

Table 3. Age indexes in the sediment samples collected at the five different coring sites in Ariake Bay.

\begin{tabular}{lcccccr}
\hline \multicolumn{1}{c}{ Criteria of age } & Age index & Kawazoe & Yanagawa & Arao & Ohama & Midorikawa \\
\hline \hline Peak of Cs-137 intensity & $1963 \mathrm{AD}$ & 15 & 25 & 10 & 40 & 60 \\
\hline Detection limit of $\mathrm{Pb}-210$ & 150 years ago & no data & 60 & 75 & 110 & unknown \\
\hline Depth of Tsunami event & $1792 \mathrm{AD}$ & 150 & 90 & 150 & no data & 210 \\
\hline & & & & & & \\
\hline \multicolumn{1}{c}{ Head } & & Kawazoe & Yanagawa & Arao & Ohama & Midorikawa \\
\hline \hline Colonized depth of $R$. philippinarum $(\mathrm{cm})$ & 50 & 80 & 100 & 108 & 80 \\
\hline Colonized age of $R$ philippinarum $(\mathrm{yBP})$ & & $1915 \mathrm{AD}$ & $1815 \mathrm{AD}$ & $1825 \mathrm{AD}$ & $1865 \mathrm{AD}$ & $1935 \mathrm{AD}$ \\
\hline
\end{tabular}




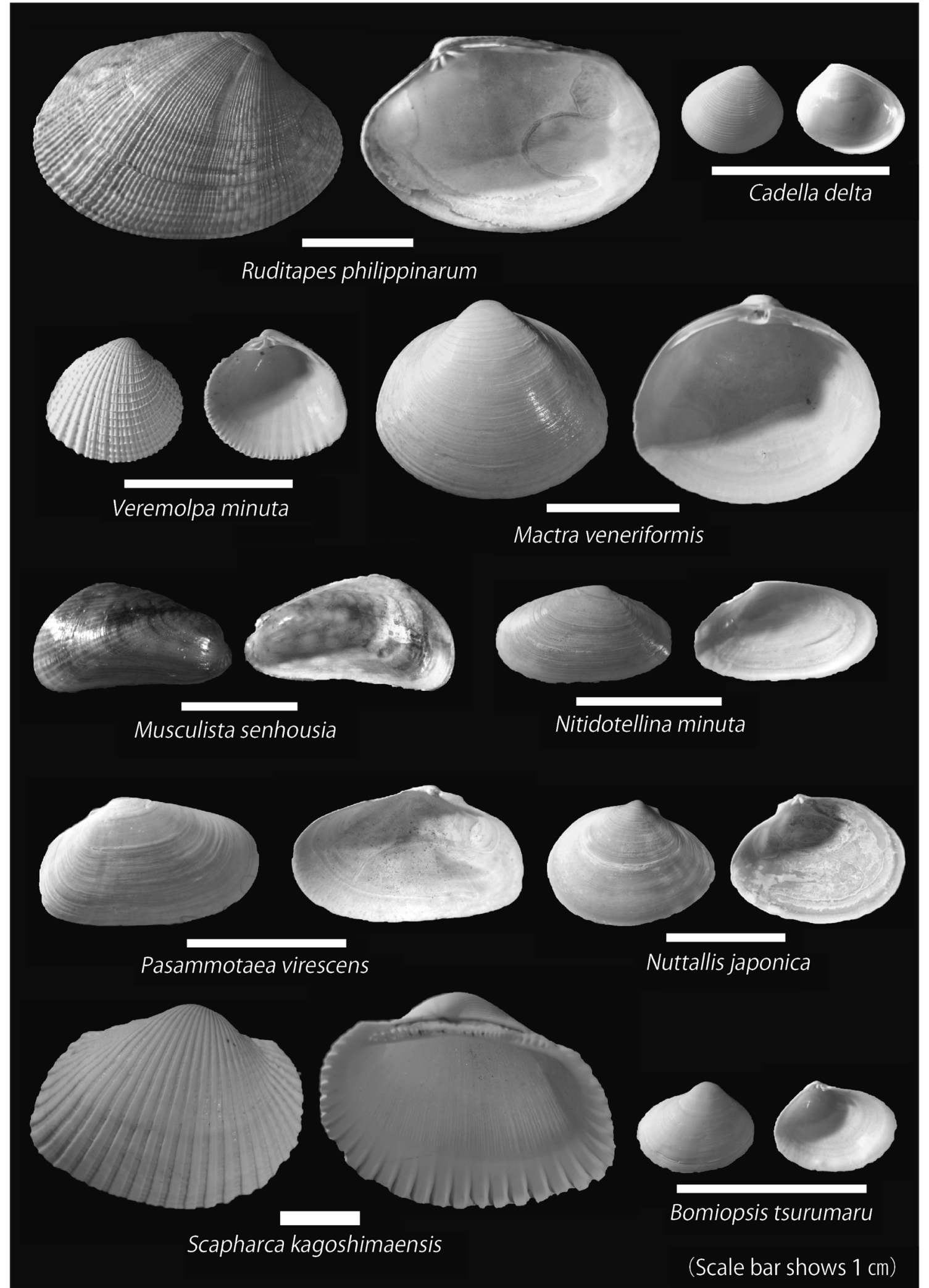

Fig. 5. Ten dominant species of fossils bivalves collected from the sediment profiles at Midorikawa in Ariake Bay on August $26,2011$. Bars indicate $10 \mathrm{~mm}$. 
contained in the sediment indicates 1963 AD, which was the global peak of ash deposition from nuclear tests (Hirose et al. 2008, Richie \& McHerry 1990). It was found at depths between 10 and $60 \mathrm{~cm}$ in the sediment profiles from the five sampling sites. The radioactive intensity of ${ }^{210} \mathrm{~Pb}$ is maximal when lava has appears on the surface of the Earth, decreasing with half-life of $22.3 \mathrm{y}$ to background levels less than $1 \%$ of the initial value within 150 years (cf. Kanai 2000). Background level was recognized at a depth of $60 \mathrm{~cm}$ from the surface at Yanagawa, $75 \mathrm{~cm}$ at Arao, and $110 \mathrm{~cm}$ at Ohama. Both the peak of radioactive intensity of ${ }^{137} \mathrm{Cs}$ and the depth of detectable radioactivity of ${ }^{210} \mathrm{~Pb}$ were located above the traces of the tsunami marked at 1792 AD.

\section{Fossil shell analysis}

Fig. 5 shows the ten dominant species in the fossil shell assemblages, including $R$. philippinarum, collected from the samples at Midorikawa, and Fig. 6 indicates the vertical profiles of the number of each species collected and the total numbers of fossil shells in one of the sediment samples. There were two peaks for the occurrence of fossil bivalves in the sample: between 50 and $70 \mathrm{~cm}$; and between 220 and $350 \mathrm{~cm}$. The former peak was composed mainly shells of $R$. philippinarum, and Mactra veneriformis. The latter was composed of shells of Cadella delta and Nuttallia japonica. Very few fossil shells of $R$. philippinarum were found in the layers below a depth of $80 \mathrm{~cm}$.

The occurrence of fossil shells of $R$. philippinarum was examined also in sediment samples collected at the other four sampling sites. Fig. 7 indicates the sediment deposition process and occurrence of fossil $R$. philippinarum were at all five sampling sites. Fossil shells of $R$. philippinarum were concentrated in the layers above depths of around $50 \mathrm{~cm}$ at Kawazoe, $80 \mathrm{~cm}$ at Yanagawa, $100 \mathrm{~cm}$ at Arao, $108 \mathrm{~cm}$ at Ohama, and $80 \mathrm{~cm}$ at Midorikawa. The limit of occurrence of fossil $R$. philippinarum was located above the trace of the 1792 tsunami at all five sampling sites.

\section{Estimation of the age of the first occurrence of gregari- ous $R$. philippinarum}

Fig. 8 illustrates the relationships between the age of different sediment layers and depth. Information on the occurrence of the fossil $R$. philippinarum (Figs. $6 \& 7$ ) enables estimation of the year of first colonization of this species at each sampling site (see Figs. $8 \&$ 9). Thus, $R$. philippinarum should be treated as an introduced species in the macro-benthic communities on the sandy tidal flats on the eastern coast of Ariake Bay from the view point of archaeology, although it is currently a dominant bivalve of the macro-benthic community.

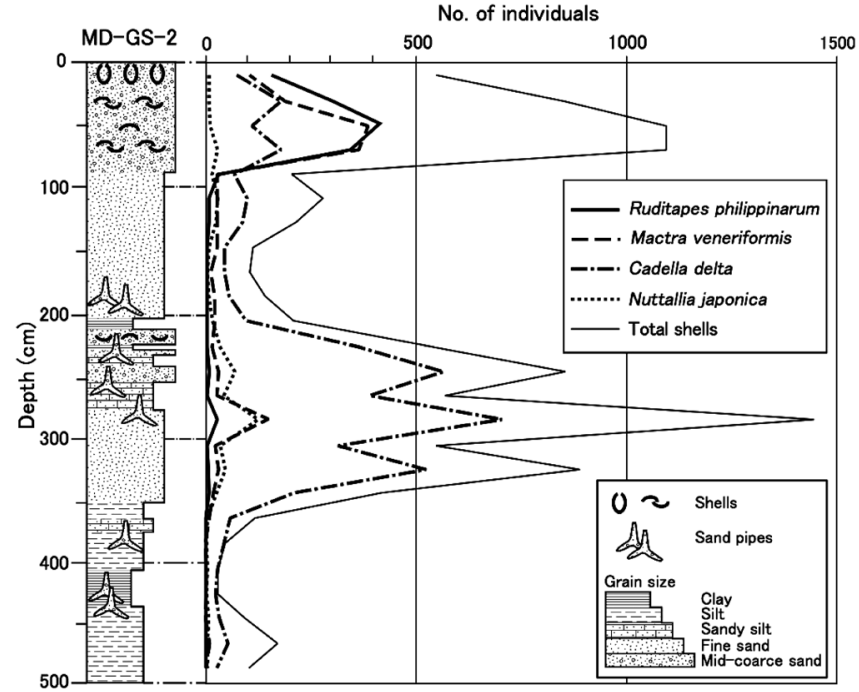

Fig. 6. Vertical profile and numbers of dominant fossil bivalve shells in a sediment profile collected at Midorikawa on August 26, 2011.

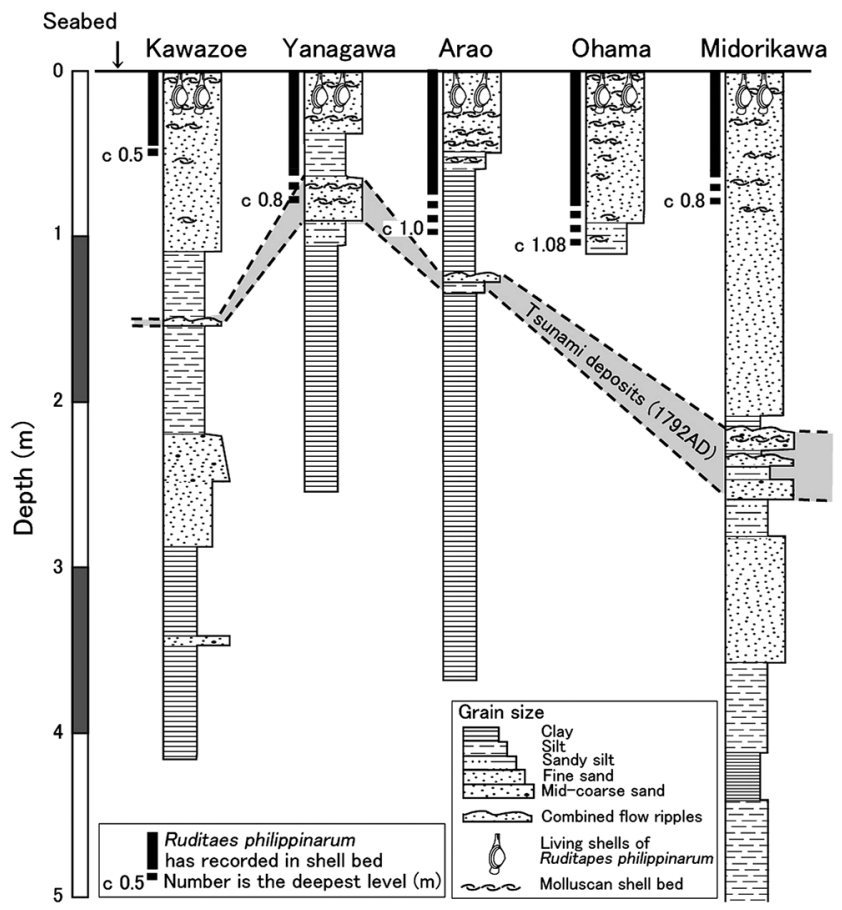

Fig. 7. Shema illustrating the vertical distribution of sediment types and deposits made by the tsunami of 1792 in the five sampling sites.

\section{Discussion}

\section{Archaeological evidences of the occurrence of Ruditapes philippinarum}

It is deduced from the results of this study that R. philippinarum was introduced to the sandy tidal flats of Ariake Bay about 180 to 190 years ago. This conclusion coincides 

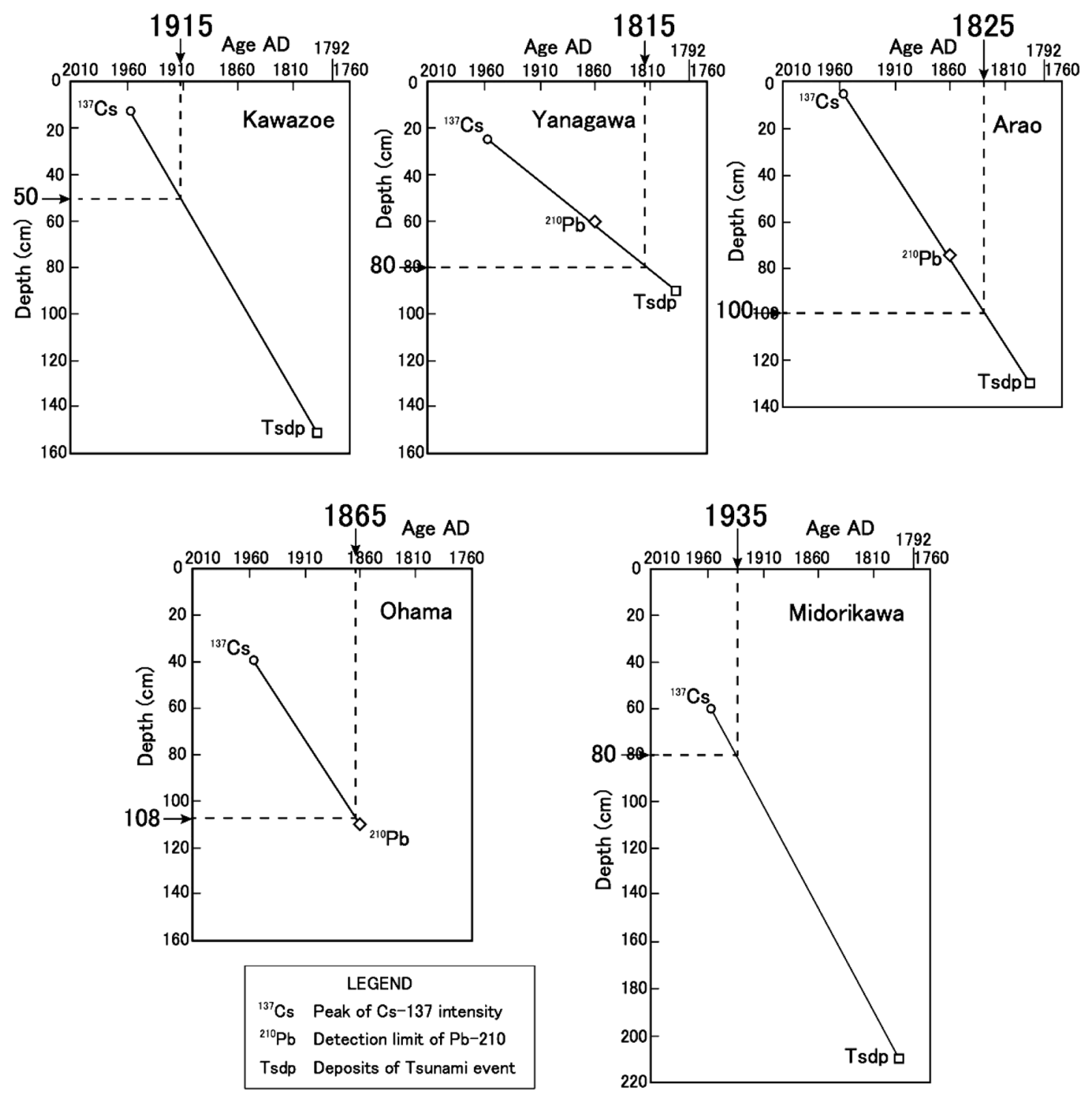

Fig. 8. Relationships between sedimentation depth and age in the sediment profiles from the 5 sampling sites, derived from 3 calibration points: the tsunami of 1792 (cf. Figs. $3 \& 4$ ), and the radioactive isotopes ${ }^{137} \mathrm{Cs}$ and ${ }^{210} \mathrm{~Pb}$ (see text and cf. Tables $2 \& 3$ ). The arrow on the ordinate and corresponding dashed line indicate the deepest depth of occurrence of fossil shell Ruditapes philippinarum (cf. also Figs. 6 \& 7); those on the abscissa indicate the corresponding estimated age.

also with the archaeological evidences from shell mounds (middens) established in the coastal areas of Ariake Bay, which were established during the Jomon to Tumulus Periods $(13,000 \mathrm{BC}$ to $600 \mathrm{AD})$. The species composition of the shell mounds reflects that of the most popular edible mollusks in those periods. Fig. 10 shows the species compositions of the mollusks in the shell mounds established in coastal areas of Ariake Bay (History of City Editing Committee of Arao City 2012, History of City Editing Committee of Itsuwa Town 2000, Editing Committee of Jyonan Town 1965, History of City Editing Committee of Tensui Town 2005, Isahaya City Education Board 2011, Itsuwa Town Education Board 2000, Kumamoto Prefecture Education Board 1978a, 1978b, 1980, 1986, 1998, 2005, Misumi Town Education Board 1979, 1984, 1998,
Oomuta City Education Board 2012, Saga Prefectural Museum 1981, Saga City Education Board 1978, Uto City Education Board 2008, 2011). According to these records, one or more of the bivalves Meretrix lusoria, Tegillarca granosa, Crassostrea gigas, or Corbicula japonica were dominated the species composition of shells in Ariake Bay middens. The dominance of $R$. philippinarum shells was particularly noticeable at shell mounds from Futowo in Amakusa Shimoshima, which is located at the mouth of Ariake Bay (Itsuwa Town Education Board 2000). These records suggest that the distribution of $R$. philippinarum was limited at the mouth of Ariake Bay (between 13,000 $\mathrm{BC}$ and $600 \mathrm{AD})$. 


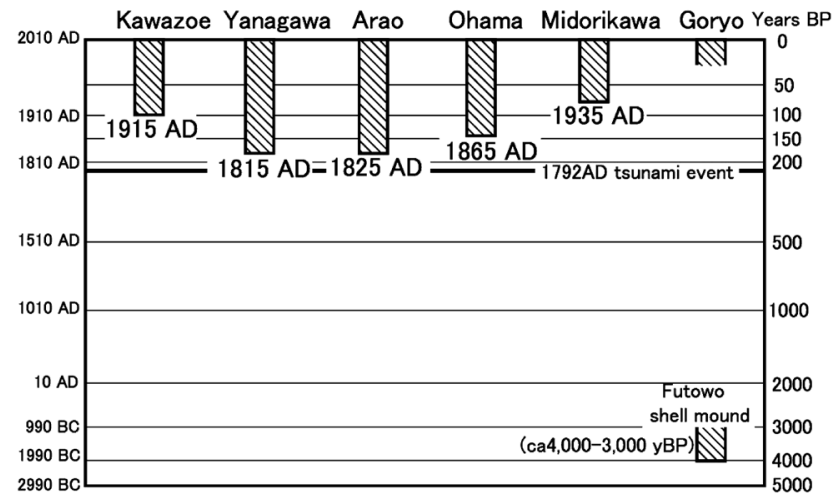

Fig. 9. The estimated range of ages at which Ruditapes philippinarum occurred at the five different sampling sites and a location with the shell mounds (Goryo) in Ariake Bay.

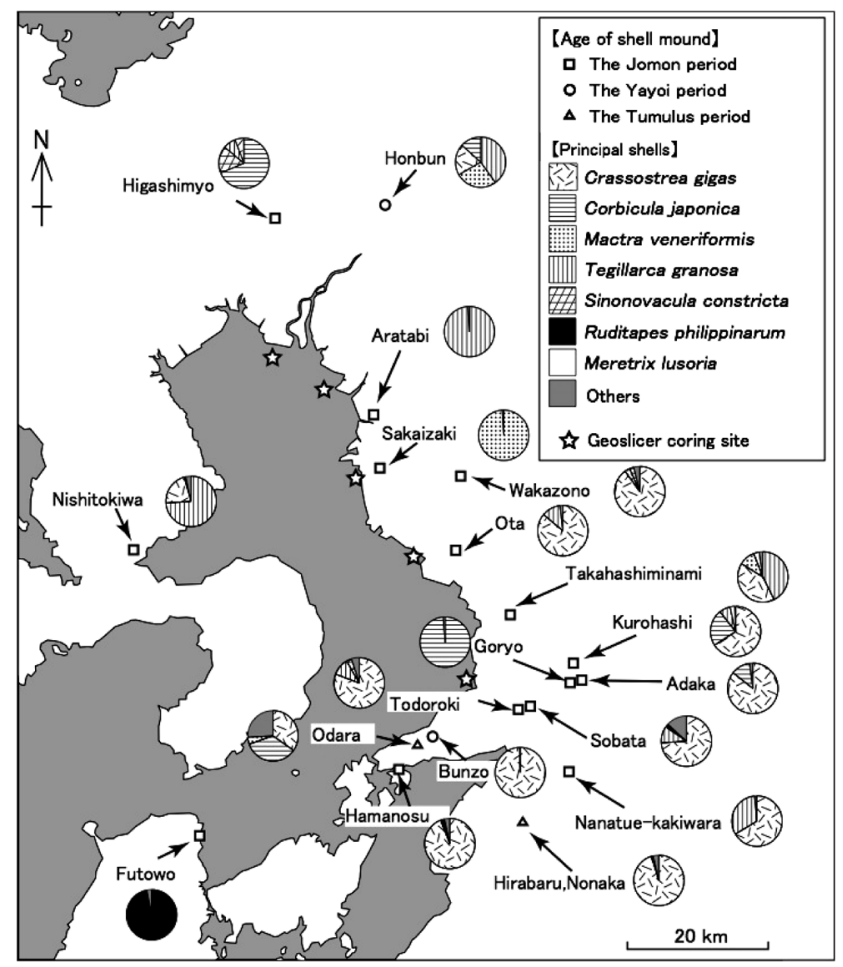

Fig. 10. Species compositions of mollusks from shell mounds (kitchen middens) in coastal areas of Ariake Bay, which were established between the Jomon and Tumulus Periods (13,000 BC to $600 \mathrm{AD})$.

\section{Extension of sand flats in Ariake Bay after the tsunami of 1792}

The sediment samples collected at the five different sites in Ariake Bay in this study provide more detailed information on the possibility of colonization by $R$. philippinarum. Sediment below traces of the 1792 tsunami consists mainly of fine particles, changing to sandy above this region (Fig. 7). The muddy sediment below the tsunami trace is not a suitable environment for the most dominant bivalves of recent sandy tidal flats, $R$. philippinarum and Mactra ven- eriformis (Fig. 6). This suggests that the tsunami caused changes to the bottom environment favoring colonization by $R$. philippinarum well before the anthropogenic introduction of $R$. philippinarum to the tidal flats in Ariake Bay about 180 to 190 years ago. It is worth noting that initial colonization by $R$. philippinarum was on the central sand flat but not mouth of Ariake Bay. It is very likely that this species was introduced to the sandy tidal flats by human hands in order to develop the coastal shellfish fishery about 180 to 190 years ago, during the mid nineteenth century.

Although the result of this study enabled deduction of an anthropogenic introduction of $R$. philippinarum to the tidal flats of Ariake Bay, the spontaneous colonization by arrival of planktonic larvae remains a probability.

\section{Conclusion}

Analysis of sediment samples was carried out to investigate the history of the $R$. philippinarum fishery in the Ariake Bay, with the results showing that it occurred within the last 200 years. The composition of shell assemblages from shell mounds dating from ca 15,000 to 1400 years ago years ago in the areas adjacent to Ariake Bay strongly support this conclusion. Although the tsunami in 1792 enlarged the sand flats and provided a suitable habitat for $R$. philippinarum in Ariake Bay, colonization began at the innermost part of Ariake Bay, which strongly suggests that it was introduced artificially.

\section{Acknowledgements}

The authors thank Dr. R.W. Gallois for his critical review of the early manuscript, and R. Lavin for his careful reading the manuscript and correction of its English text. We are also grateful to Mr. K Mizukami of Kumamoto Prefecture Education Board for his helpful support to refer the excavation reports of shell mounds in Kumamoto Prefecture. This work was partly supported from The Ariake Bay Rehabilitation Organization, and The Mitsui \& Co., Ltd. Environment Fund. The anonymous reviewers of The Plankton \& Benthos Research are also acknowledged for their helpful comments, suggestions and improvement.

\section{References}

Aishima N (1993) Asari chigai no sensa koudo ni oyobosu suion to enbun no eikyou [Effects of water temperature and salinity on burrowing behavior in juvenile short-neck clam Ruditapes philippinarum]. Bulletin of Fukuoka Fisheries and Marine Technology Research Center 1: 145-150. (in Japanese)

Choi KS, Park K (2010) Review on the protozoan parasite Perkinsus olseni (Lester and Davis 1981) infection in Asian waters. In: Coastal Environmental and Ecosystem Issues of the East China Sea (eds Ishimatsu A, Lie HJ, TERRAPUB). Nagasaki University, 269-281.

Environment Agency (1994) Dai yonkai sizenkankyo hozen kiso 
chosa [The 4th Basic Survey for the Conservation of the Natural Environment, Report on the Coastal Fauna and Environment (Surveys on the Tidal Flats, Algal Bed and Coral Reef)]. Vol. 1, Tidal flats. Nature Conservation Bureau, Environment Agency, 291 pp. (in Japanese)

FAO (2015) FAOSTAT Fisheries \& Aquaculture data. Ruditapes philippinarum Available at: http://apps.fao.org/fishery/ culturedspecies/Ruditapes philippinarum/en.

Haraguchi T, Nakata T, Shimazaki K, Imaizumi T, Kojima K, Ishimaru T (1998) A new sampling method of unconsolidated sediments by long geo-slicer, a pile-type soil sampler. Journal of the Japan Society Engineering Geology 39: 306-314. (in Japanese with English abstract)

Hirose K, Igarashi Y, Aoyama M (2008) Analysis of the 50-year records of the Atmospheric deposition of long-lived radionuclides in Japan. Applied Radiation of Isotopes 66: 1675-1678.

History of City Editing Committee of Arao City (2012) Arao shisi tsusi hen [Overview, The History of Arao City]. Arao City, 1598 pp. (in Japanese)

History of City Editing Committee of Itsuwa Town (2000) Itsuwa cho-si [The History of Itsuwa Town]. Itsuwa Town, 133 pp. (in Japanese)

History of City Editing Committee of Jyonan Town (1965) Jhonan cho-si [The History of Jhonan Town]. Jhonan Town, 1005 pp. (in Japanese)

History of City Editing Committee of Tensui Town (2005) Tensui cho-si [History of Tensui Town]. Tensui Town, 1036 pp. (in Japanese)

Isahaya City Education Board (2011) Nishitokiwa kaizuka sono $n i$ [Nishitokiwa shell mound, Part 2]. In: Investigation Report of Buried Cultural Properties in Isahaya City 25. Isahaya City, pp. 1-39. (in Japanese)

Ishii R, Sekiguchi H, Nakahara Y, Jinnai Y (2001) Laval recruitment of the manila clam Ruditapes philippinarum in Ariake Sound, southern Japan. Fisheries Science 67: 579-591.

Itsuwa Town Education Board (2000) Futowo kaizuka [Futowo shell mound]. Itsuwa Town, 123 pp. (in Japanese)

Kakino J (2000) Habitat conditions and large scale propagation on Japanese littleneck clam Ruditapes philippinarum. Aquabiology 127: 143-154. (in Japanese with English abstract)

Kakino J (2006) Study on the effects of physical and chemical environmental factors on the Japanese littleneck clam Ruditapes philippinurum. Fisheries Engineering 43: 117-130. (in Japanese with English abstract)

Kanai, Y. (2000) Namari no chikyu kagaku [Geochemistry of lead, especially sediemntological application of lead-210]. Chishitsu News, no. 556, 20-34. (in Japanese)

Katayama N (1974) Old records of Natural Phenomena concerning the "Shimabara Catastrophe". Sci. Rept. Shimabara Volcano Observatory, Science Report, Shimabara Volcano Observatory, Faculty of Science Kyushu University, 9: 1-45. (in Japanese with English abstract)

Kikuchi T (2000) 12 Meaning of conservation of ecosystem on the tidal flats and shallow waters (Higata senkaikei no hozen no igi). In: Life in Ariake Sea (Ariakekai no Ikimono Tachi) (ed Sato M), Kaiyusha, Tokyo, 314-317. (in Japanese)

Komorita K, Shibanuma S, Yamada T, Kajihara R, Tsukuda M, Montani S (2009) Impact of low temperature during the winter on the mortality in the post-settlement period of the juvenile of short-neck clam, Ruditapes philippinarum, on the tidal flats in Hichirippu Lagoon, Hokkaido, Japan. Plankton Benthos Res 4: 31-37.

Kudo K, Aramaki S, Tokitou K, Ikeda K (2006) Fishery environment, sexual maturity, recruitment and growth of Japanese short-necked clam, Ruditapes philippinurum (Adams \& Reeve), on the estuary of the Banjo River in Saeki Bay. Fisheries Engineering 42: 259-266. (in Japanese with English abstract)

Kumamoto Prefecture Education Board (1978a) Takahashiminami kaizuka [Takahashiminami Shell Mound]. Investigation Report of Cultural Properties 28, Kumamoto Prefecture, 121 pp. (in Japanese)

Kumamoto Prefecture Education Board (1978b) Nishitokiwa kaizuka [Nishitokiwa Shell Mound]. Results of investigation for the buried Cultural Properties in the Basin of the River Kikuchi. Investigation report of Cultural Properties 31, Kumamoto Prefecture, 136 pp. (in Japanese)

Kumamoto Prefecture Education Board (1980) Hirabaru Nonaka kaizuka [Hirabaru and Nonaka Shell Mounds]. Investigation report of Cultural Properties 43, Kumamoto Prefecture, 123 pp. (in Japanese)

Kumamoto Prefecture Education Board (1986) Nanatsuekakiwara Takenoshita Kaizuka [Nanatsuekakiwara and Takenoshita shell mounds]. In: Investigation Report of Cultural Properties 79. Kumamoto Prefecture, pp. 1-89. (in Japanese)

Kumamoto Prefecture Education Board (1998) Kurohashi kaiduka [Kurohashi Shell Mound]. Investigation report of cultural properties 166, Kumamoto Prefecture, 293 pp. (in Japanese)

Kumamoto Prefecture Education Board (2005) Ataka kaizuka [Ataka Shell Mound]. Investigation Report of Cultural Properties 223. Kumamoto Prefecture, 224 pp. (in Japanese)

MacArthur RH, (1960) On the relative abundance of species. The American Naturalist, 94: 25-36.

Magni P, Montani S, Takada C, Tsutsumi H (2000) Temporal scaling and revevance of bivalve nutrient excretion on a tidal flat on the Seto Inland Sea, Japan. Marine Ecology Progress Series, 198: 139-155.

Matsukawa Y, Cho N, Katayama S, Kamio K (2008) Wagakuni no asari. Factors responsible for the drastic catch decline of the manila clam Ruditapes philippinarum in Japan. Nippon Suisan Gakkaishi 74: 137-143. (in Japanese with English abstract)

Ministry of Agriculture, Forestry and Fisheries (2014) Statistical tables, XI Fishery, 4 Fishery and agriculture production, (2) Production and values of major fish. In: The 87th Statistical Yearbook of Ministry of Agriculture, Forestry, and Fisheries (2011 2012), Ministry of Agriculture, Forestry and Fisheries. Available at: http://www.e-stat.go.jp/SG1/estat/List. do?lid $=000001116218$ (accessed on March 18, 2014)

Ministry of Environment (2006) Ariakekai Yatsushirokai Sougou Chousa Hyouka Iinkai houkoku [Committee Report]. Ariake Bay and Yatsushiro Sea Inegrated Survey Evaluation Committee, Ministry of Environment, Government of Japan, 80 pp. Available at: http://www.env.go.jp/council/20ari-yatsu/ rep061221/all.pdf (accessed on March 30, 2014) (in Japanese)

Misumi Town Education Board (1979) Odara kofun [Odara Ancient Tomb]. Odara Ancient Tomb, Investigation Report of 
Cultural Properties in Misumi Town, Misumi Town, 70 pp. (in Japanese)

Misumi Town Education Board (1984) Bunzo kaizuka [Bunzo Shell Mound]. Investigation Report of Cultural Properties in Misumi Town 2, Misumi Town, 23 pp. (in Japanese)

Misumi Town Education Board (1998) Hamanosu kaizuka [Hamanosu Shell Mound]. Investigation Report of Cultural Properties in Misumi Town 8, Misumi Town, 28 pp. (in Japanese)

Mizuno T, Maruyama T. Higano J (2009) Transition and prospect of Asari clam (Ruditapes philippinurum) fisheries in Ise Bay. Bulletin of Mie Prefecture Fisheries Research Institute 17: 1-21. (in Japanese with English abstract)

Nakata T, Shimazaki K (1997) Geo-slicer, a newly invented soil sample, for high-resolution active fault studies. Journal of Geography 106: 59-69. (in Japanese with English abstract)

Nakahara Y, Nasu H (2002) Report from the coastal areas of Ariake Sound, Kumamoto Prefecture; the main fisheries ground for the clan Ruditapes philippinarum population in Japan. Japanese Journal of Benthology 57: 139-144. (in Japanese with English abstract)

Ohkoshi K (2004) Alien species introduced with imported clams: the clam-eating moon snail Euspira fortunei and other unintentionally introduced species. Japanese Journal of Benthology 59: 74-82. (in Japanese with English abstract)

Oomuta City Education Board (2012) Aratabi kaizuka [Aratabi Shell Mound]. Investigation Report of Aratabi Shell Mound, Oomuta City, 46 pp. (in Japanese)

Reimer PJ, Baillie MGL, Bard E, Bayliss A, Beck JW, Blackwell PG, Ramsey CB, Buck CE, Burr GS, Edwards RL, Friedrich M, Grootes PM, Guilderson TP, Hajdas I, Heaton TJ, Hogg AG, Hughen KA, Kaiser KF, Kromer B, McCormac FG, Manning SW, Reimer RW, Richards DA, Southon JR, Talamo S, Turney CSM, Plicht J, Weyhenmeyer CE (2009) IntCal09 and Marine09 radiocarbon age calibration curves, $0-50,000$ years cal BP. Radiocarbon 51: 1111-1150.

Richie JC and McHerry JR (1990) Application of radioactive fallout Cesium-137 for measuring soil erosion and sediment accumulation rates and patterns: review. Journal of Environmental Quality 19: 215-233.

Saga Prefectural Museum (1981) Honbun kaizuka [Honbun Shell Mound]. Nishijima, Mine Town, Miyaki District, Saga Prefecture. Investigation Research Note Saga Prefectural Museum 7. Saga Prefectural Museum, 70 pp. (in Japanese)

Saga City Education Board (1978) Higashimyou iseki niji hisadomi nihonsugi iseki [The Second Report of the Ruin Group of Higashimyo and Hisadomi-Nihonsugi.] Investigation Report for the Buried Cultural Properties in Saga City 40, $6^{\text {th }}$ Book, Saga City, 326 pp. (in Japanese)

Sasaki K (1999) Material circulation and production in estuary and tidal flat-35, Tidal flat and fishery resources 4, Japanese littleneck clam of Ariake Sea. Aquabiology 121: 162-166. (in Japanese with English abstract)

Seikai National Fisheries Research Institute, Fisheries Research Agency (2014) Ariakekai Yatsushirokai tou no suisitsu kansoku jyouhou [Information of water quality monitoring in Ariake Bay and Yatsushiro Bay]. Available at: http://ariakeyatsushiro.jp/ariake/danmen/danmen_hiduke/danmen_top. htm. (in Japanese) (accessed on 18 March 2014)

Sekiguchi H, Ishii R (2003) Drastic decreasing of annual catch yields of the manila clam Ruditapes philippinarum in Ariake Sound, Southern Japan. Oceanography in Japan 12: 21-36. (in Japanese with English abstract)

Shimo S, Akimoto Y, Takahama H (2004) Review of the water quality effects on marine organisms. Report of Marine Ecology Research Institute 6: 1-159. (in Japanese with English abstract)

Shimoyama S, Hamano T (1990) The effect of oxigen-deficient water for the molluscan thanatocoenosis in Hakata Bay. In: Proceedings of the Fourth Symposium on Ecology and Paleoecology of Benthic Communities (ed Robba E.), Sorrento 1-5, Nov. 1988: Meusio Regionale di Scienze Natural di Trino, 822 pp.

Shinohara M, Tokuda M, Sudino K (2009) Fukuokaken ariakesan no asari no ryutsu ni tsuite [Distribution of Japanese littleneck clams], Ruditapes philippinarum Adams \& Reeve, from the intertidal flats in the Ariake Sea, Kyushu, western Japan]. Bulletin of Fukuoka Fisheries And Marine Technology Research Center 19: 157-161. (in Japanese)

Stuiver M, Polach HA (1977) Discussion: Reporting of ${ }^{14} \mathrm{C}$ data, Radiocarbon 19: 355-363.

Takahashi M (1994) Ocean, living being and man-7. Bays and inland seas and their current conditions. Aquabiology 16: 2-5. (in Japanese with English abstract)

Tamaki A (2004) Dynamics of benthic communities on intertidal sandflats in the Ariake Sound estuarine system, with special reference to the recent decline in the manila clam yield. Journal of Japan Society on Water Environment 27: 301-306. (in Japanese with English abstract)

Tsukuda M, Yamaguchi H, Takahashi T, Tsutsumi H (2008) Impact of high concentrations of manganese on the survival of short neck clam Ruditapes philippinurum juveniles in sandy tidal flat sediment in Ariake Bay, Kyushu, Japan. Plankton Benthos Res 3: 1-9.

Tsutsumi H, Ishizawa K, Tomishige M, Moriyama N, Sakamoto K, Montani S (2002) Population dynamics of a clam, Ruditapes philippinarum, on an artificially created sand cover on the tidal flats at the river mouth of Midorikawa River. Japanese Journal of Benthology 57: 177-187.

Tsutsumi H (2003) Higata no kiki [Recent happenings on the tidal flats in Kumamoto]. Seibutsu no Kagaku Iden 57: 41-45. (in Japanese)

Tsutsumi H (2005) Marked decline of clam harvesting fisheries and environmental changes on the tidal flats facing Ariake Sea in Kumamoto Prefecture. Ecology and Civil Engineering Society 8: 83-102. (in Japanese with English abstract)

Tsutsumi H (2006) Review: critical events in the Ariake Bay ecosystem: clam population collapse, red tides, and hypoxic bottom water. Plankton Benthos Res 1: 3-25.

Tsutsumi H, Tsutsumi A, Takamatsu A, Kimura C, Nagata S, Tsukuda M, Komorita T, Takahashi T, Montani S (2007) Mechanisms for expansion of hypoxic water in the inner areas of Ariake Bay during summer. Oceanography in Japan 16: 183-202.

Tsutsumi H, Nomura R, Tanoue T, Komorita T, Iwasaki T, Fujimori $\mathrm{T}$ (2013) Influence of the development and destruction 
of muddy byssal mats made by a mytilid mussel, Musculista senhousia, on seasonal fluctuations of the macrobenthic community on sandy tidal flats. Japanese Journal of Benthology 67: 47-55.

Uto City Education Board (2008) Todoroki Kaizuka [Todoroki shell mound]. Reinvestigation Report of the Excavation Samples by Keio University, Uto City 30, 197 pp. (in Japanese)

Uto City Education Board (2011) Sobata Kaizuka [Sobata Shell Mound]. Reinvestigation Report of the Excavation Samples by Keio University, Uto City 32. Uto City, 195 pp. (in Japanese) 